\title{
Endothelin-1 in smooth muscle cells and mast cells of mouse uterus after parturition
}

\section{Tsuyoshi Uchide ${ }^{1,2}$, Javier Adur ${ }^{1}$, Kazuki Yoshioka ${ }^{3}$, Takushi Sasaki ${ }^{2}, K_{0}$ osuke Temma ${ }^{2}$ and Kaname Saida ${ }^{1}$}

\author{
${ }^{1}$ National Institute of Advanced Industrial Science and Technology (AIST), Ministry of Economy, \\ Trade and Industry (METI), Tsukuba, Ibaraki 305-8566, Japan \\ ${ }^{2}$ Department of Toxicology, School of Veterinary Medicine and Animal Sciences, Kitasato University, \\ Towada, Aomori, 034-8628, Japan \\ ${ }^{3}$ Department of Veterinary Anatomy, School of Veterinary Medicine and Animal Sciences, \\ Kitasato University, Towada, Aomori, 034-8628, Japan \\ (Requests for offprints should be addressed to T Uchide, Department of Toxicology, School of \\ Veterinary Medicine and Animal Sciences, Kitasato University, 35-1, Higashi 23-bancho, Towada, \\ Aomori 034-8628, Japan; Email: uchide@vmas.kitasato-u.ac.jp or K Saida, National Institute of \\ Advanced Industrial Science and Technology, 1-1 Higashi, Tsukuba, Ibaraki 305-8566, Japan; \\ Email: k.saida@aist.go.jp)
}

\begin{abstract}
To elucidate the physiological importance of endothelin-1 (ET-1) in mouse uterus, we investigated quantitative changes in ET-1 mRNA levels in the uterus during the estrous cycle, pregnancy and post-parturient period by use of the real-time PCR technique and we examined the cellular distribution of the ET-1 peptide by use of immunohistochemical techniques. Low and constant mRNA levels were observed in the uterus from cyclic or pregnant mice. However, a significant increase in $\mathrm{mRNA}$ levels was found immediately after parturition (day 0 postpartum) which then decreased gradually to a basal
\end{abstract}

level at day 14 postpartum. Discernible immunopositivity was found in myometrial cells as well as in endometrial epithelial cells in the post-parturient uterus. Myometrial cells showed the strongest staining at day 0 postpartum, and some large cells in the myometrial layers, intensely positive for ET-1, were characterized as mast cells. These findings suggest the possibility that in mouse uterus ET-1 may play a role in recovery from the uterine changes caused by pregnancy and parturition.

Fournal of Molecular Endocrinology (2001) 27, 165-173

\section{INTRODUCTION}

Endothelin-1 (ET-1) is a potent vasoconstrictor peptide originally isolated from the culture supernatant of endothelial cells (Yanagisawa et al. 1988). Three isotypes of endothelin, known as ET-1, ET-2/vasoactive intestinal contractor (VIC), and ET-3, encoded by separate genes, have been found in mammals (Inoue et al. 1989, Saida et al. 1989, Bloch et al. 1991). These isopeptides have a variety of biological activities including vasoconstriction (Yanagisawa et al. 1988), smooth muscle contraction (Ishida et al. 1989, Mckay et al. 1991), and cell growth (Lahav et al. 1996, Mazzocchi et al. 1997). Biological effects are mediated by two cell-surface receptor subtypes, the endothelin A (ETA) and endothelin B (ETB) receptors. Many reports on both endothelins and their receptors in the uterus have been published (see review by Rubanyi \& Polokoff 1994). Detailed investigation of the gene expression level and the cellular distribution of the ET-1 mRNA and peptide has been performed in various mammalian species including human (Economos et al. 1992, O’Reilly et al. 1992, Cameron et al. 1993), sheep (Riley et al. 1994, 1995), rabbit (Maggi et al. 1991, Peri et al. 1992), and mouse (Uchide et al. 1999). However, no one has yet confirmed a significant physiological role for uterine ET-1. The uterus, a physiologically active tissue, is composed of many types of cells and undergoes functional and morphological cellular changes in response to various reproductive events 
including estrous cycle, menstrual cycle, pregnancy, and the post-parturient period. Additionally, important physiological and anatomical distinctions (e.g. differences in placental structure and function during pregnancy and in endometrial structure and function during estrous or menstrual cycles) exist among different species. This complexity, unique to the uterus, has made it difficult to ascertain the physiological role of uterine ET-1.

Recently, we demonstrated a relatively high level of expression of ET-1 and VIC mRNA in mouse uterus by semi-quantitative reverse transcriptionpolymerase chain reaction (RT-PCR) (Uchide et al. 1999). In addition, we performed a comprehensive analysis on gene expression and cellular distribution of VIC during the estrous cycle, pregnancy, and the post-parturient period, and our results suggested an important role for VIC in the function of myometrial cells. However, detailed information on ET-1 throughout the various physiological stages has not yet been obtained in mouse uterus.

To understand the physiological roles of ET-1 in the uterus, it is necessary to compare many pieces of information on ET-1 from various species, while considering physiological and anatomical differences. In this paper, we extend the comprehensive analysis of gene expression and cellular distribution carried out on VIC to ET-1 in mouse uterus. We discuss the physiological role of ET-1 in mouse uterus.

\section{MATERIALS AND METHODS}

\section{Mice}

Adult (10-week-old) male and female Slc:ICR mice were obtained from Japan Clea (Tokyo, Japan). Mice were mated, and the day of the vaginal plug and the day of parturition were designated day 0 of pregnancy and day 0 postpartum respectively. Pregnant mice at days $7,8,9,10,12,15$, and 17 of pregnancy $(\mathrm{P}-7,8,9,10,12,15$, and 17), non-pregnant mice at different stages of the estrous cycle (proestrus, estrus, and diestrus), and parturient mice at days $0,1,3,7$, and 14 postpartum (D-0, 1, 3, 7, and 14) were used for the experiment. Each group contained three mice $(n=3)$. Our experimental procedures on animal subjects were in accordance with the Guidelines on Handling of Laboratory Animals for our institution.

\section{RNA preparation}

The uteri excised from these mice were homogenized, and total RNAs were then prepared from the homogenate using a commercial phenol and guanidine-thiocyanate solution (Isogen solution; Nippon Gene, Tokyo, Japan) according to the manufacturer's protocol. Briefly, the excised tissue $(100 \mathrm{mg})$ was homogenized in $1 \mathrm{ml}$ Isogen solution, and $0.2 \mathrm{ml}$ chloroform was added. After centrifugation at $12000 \mathrm{~g}$ for $15 \mathrm{~min}$, the aqueous phase (upper layer) was collected into another tube. To avoid contamination of genomic DNA into the sample, the purification step was repeated once more after mixing the aqueous phase with Isogen solution. Then $0.5 \mathrm{ml}$ isopropanol was added, and total RNA precipitate was obtained by centrifugation at $12000 \mathrm{~g}$ for $15 \mathrm{~min}$.

\section{Gene expression analysis}

We performed gene expression analysis using a real-time PCR technique as described in a previous report (Uchide et al. 2000a). After reverse transcriptase reaction of total RNAs, cDNAs obtained were used as templates for the real-time PCR. Oligonucleotide primers and detection probes (which were labeled with a reporter dye (FAM: 6-carboxy-fluorescein) at the $5^{\prime}$ end and a quencher dye (TAMRA: 6-carboxy-tetramethyl-rhodamine) at the $3^{\prime}$ end) for mouse ET-1 and glyceraldehyde3-phosphate dehydrogenase (GAPDH) were designed (Table 1). Amplification was carried out using the TaqMan PCR kit (PE Applied Biosystems, Foster City, CA, USA). Template was mixed with $1 \times$ buffer, $3.5 \mathrm{mM} \mathrm{MgCl}_{2}$, $200 \mu \mathrm{M}$ dATP, dCTP, dGTP, and $400 \mu \mathrm{M}$ dUTP, $0.025 \mathrm{U} / \mu \mathrm{l}$ AmpliTaq Gold polymerase, $100 \mathrm{nM}$ TaqMan probe, and $200 \mathrm{nM}$ of each primer. All reactions were performed in the Model 7700 Sequence Detector (PE Applied Biosystems). Reaction conditions were $95{ }^{\circ} \mathrm{C}$ for $10 \mathrm{~min}$ followed by 50 cycles of the amplification step $\left(95^{\circ} \mathrm{C}\right.$ for $20 \mathrm{~s}$ and $62{ }^{\circ} \mathrm{C}$ for $2 \mathrm{~min}$ ). The specific amplification was confirmed by electrophoresis and sequence of PCR products. The absence of genomic DNA contamination in template was confirmed by a mock RT experiment. The gene expression levels of ET-1 are represented as gene expression rates normalized by those of GAPDH as previously reported (Uchide et al. 1999). Briefly, ET-1 and GAPDH cDNA levels were estimated using standard curves obtained by amplification of standard cDNAs. Then the gene expression rates were calculated using the following formula:

\section{(ET-1 cDNA level/GAPDH cDNA level) $\times 100$}

\section{Histochemical analysis}

Immunohistochemistry was performed using a rabbit immunoglobulin $\mathrm{G}(\mathrm{IgG})$ antibody against 
TABle 1. Specific primers and TaqMan probes for real-time PCR

\begin{tabular}{|c|c|c|}
\hline & Primer/probe & $\begin{array}{l}\text { Position on } \\
\text { cDNA (n.t.) }\end{array}$ \\
\hline \multicolumn{3}{|l|}{ Gene } \\
\hline \multirow[t]{3}{*}{ ET-1 } & 5'-'TTCCCGTGATCTTCTCTCTGCT-3' (sense) & $41-63$ \\
\hline & 5'-TCTGCTTGGCAGAAATTCCA-3' (antisense) & $391-410$ \\
\hline & 5'-FAM-ACAAGGAGTGTGTCTACT'TCTGCCACCTGG-TAMRA-3' & $209-228$ \\
\hline \multirow[t]{3}{*}{ GAPDH } & 5'-CTTCACCACCATGGAGAAGGC-3' (sense) & $343-363$ \\
\hline & 5'-GGCATGGACTGTGGTCATGAG-3' (antisense) & $560-580$ \\
\hline & 5'-FAM-CCTGGCCAAGGTCATCCATGACAACTTT-TAMRA-3' & $517-544$ \\
\hline
\end{tabular}

n.t., nucleotide.

ET-1 peptide (polyclonal antibody for immunohistochemistry; Code No. 18201, IBL, Gunma, Japan). Crossreactivity studies showed that this antibody reacted at $100 \%$ with ET-1 but below $1 \%$ with other members of the ET family, as indicated

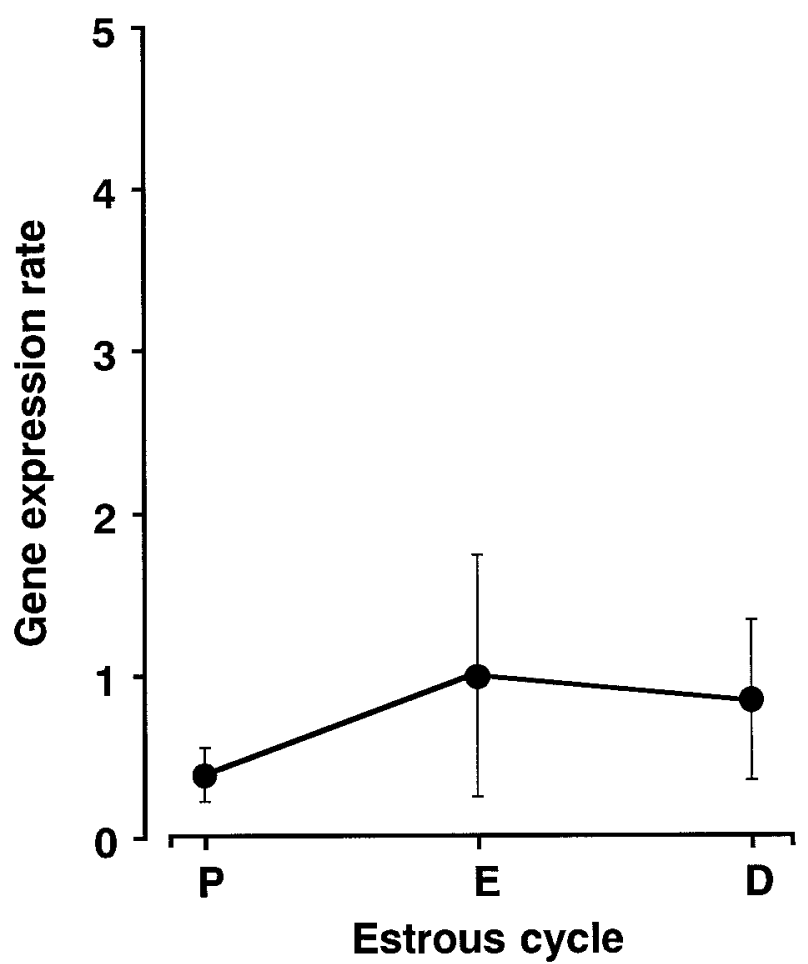

FIGURE 1. Gene expression rates of ET-1 during the estrous cycle. ET-1 and GAPDH mRNA levels in proestrus (P), estrus (E), and diestrus (D) were quantitatively analyzed by real-time PCR. Gene expression rates were calculated by normalizing the mRNA levels of ET-1 with those of GAPDH.

Quantification was independently performed using three individual mice for each stage $(n=3)$. A low and almost unchanged level of expression was observed. by the manufacturer. Excised uteri were fixed with $4 \%$ (wt/vol) paraformaldehyde and embedded in paraffin by standard methods. Sectioned tissues at a thickness of $4 \mu \mathrm{m}$ were deparaffinized and rehydrated with graded alcohol. After washing with PBS, the sections were treated with methanol containing $0.3 \%$ hydrogen peroxide for $30 \mathrm{~min}$ to inactivate endogenous peroxidase activity.

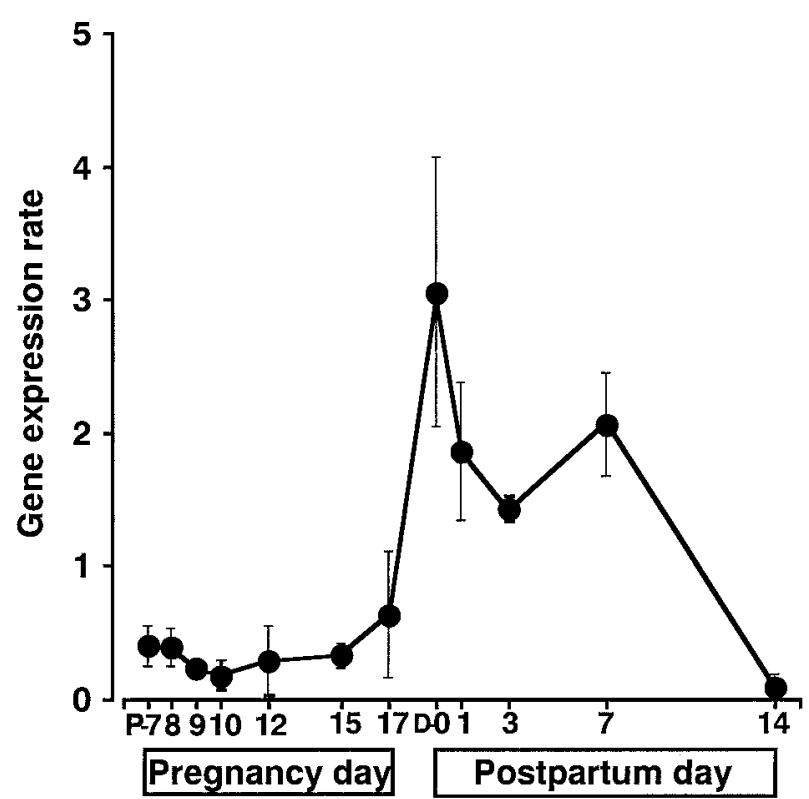

FIGURE 2. Gene expression rates of ET-1 during pregnancy and after parturition. The uteri at days 7,8 , $9,10,12,15$, and 17 of pregnancy $(\mathrm{P}-7,8,9,10,12,15$, and 17 ) and at days $0,1,3,7$, and 14 postpartum (D-0, $1,3,7$, and 14) were used for quantification of ET-1 and GAPDH mRNA levels. Gene expression rates were calculated by normalizing mRNA levels of ET-1 with those of GAPDH. Quantification was independently performed using three individual mice for each stage $(n=3)$. A remarkable increase in expression levels was observed after parturition. 

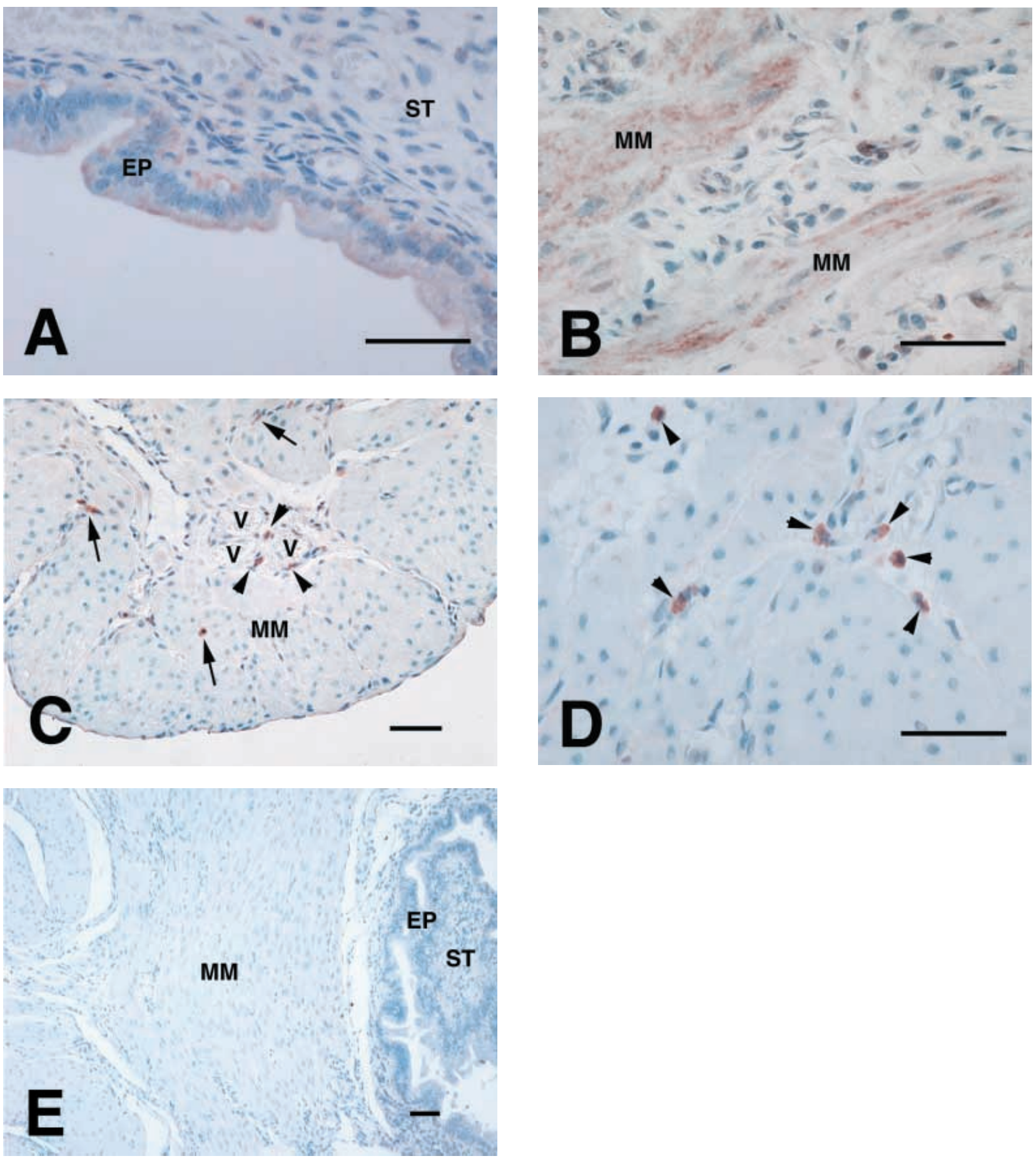

FIGURE 3. Immunolocalization of ET-1 in the mouse uterus after parturition. Immunostaining with an antibody specific to ET-1 peptide was carried out in the post-parturient uterus (at day 0 postpartum). Positive signals were visualized by DAB (brown staining). (A) Endometrial epithelial cells were positive for ET-1. (B) Myometrial cells were intensely stained. Relatively large and round- or oval-shaped cells intensely positive for ET-1 (D, arrow heads) were mainly found around vessels in the myometrium ( $\mathrm{C}$, arrow heads), and between myometrial cells (C, arrows). The immunostaining was completely suppressed in the negative control study without the first antibody (E), and also in the control study with non-immune IgG or pre-absorbed first antibody (data not shown). Counterstaining for nuclei was carried out with Mayer's hematoxylin. EP, epithelium; ST, stroma; MM, myometrium; V, vessel. Bars =50 $\mu$ m. 


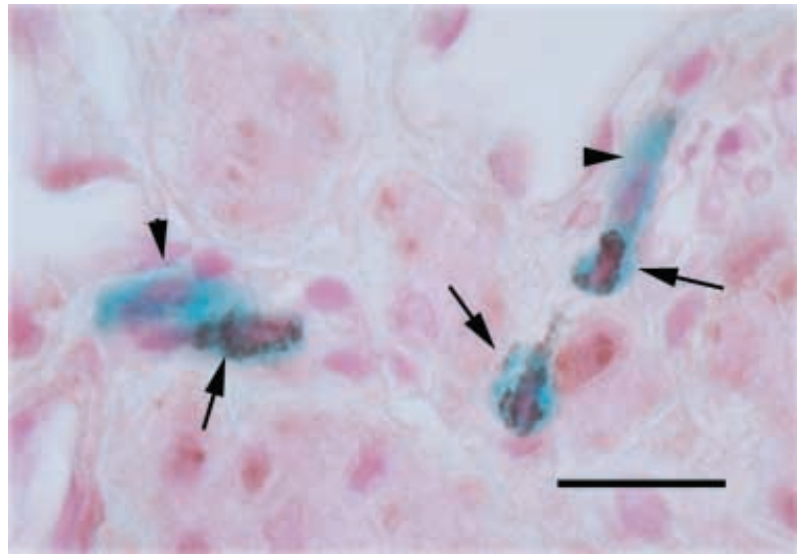

FIGURE 4. Double staining with anti-ET-1 antibody and Alcian Blue. After ET-1-positive signals were visualized with DAB (brown staining) in the uterus at day 0 postpartum, cytochemical staining with Alcian Blue, which stains acidic mucopolysaccharide which is abundant in mast cells, was carried out. Positive cells are stained light blue. Kernechtrot solution was used for counter stain (light red). The round- or oval-shaped and ET-1-positive cells in the myometrial layers shown in Fig. 3 were stained with Alcian Blue (light blue). Brown ET-1-positive signals are found in the cytoplasm colored light blue and around nuclei stained light red (cells designated by arrows). ET-1-negative and Alcian Blue-positive cells were also observed as a small population (arrow heads). Bar $=20 \mu \mathrm{m}$.

Immunostain was carried out using a commercial kit (Vectastain ABC Kit, Vector Lab., Burlingame, CA, USA). Briefly, the sections were washed with PBS and incubated in 10\% normal goat serum in PBS for $30 \mathrm{~min}$ to block nonspecific immunoreactive sites. The sections were then reacted with $5 \mu \mathrm{g} / \mathrm{ml}$ anti-ET-1 rabbit antibody for $60 \mathrm{~min}$ at room temperature. After being washed with PBS, the sections were incubated with biotinylated goat anti-rabbit $\mathrm{IgG}$ for $30 \mathrm{~min}$ at room temperature, washed with PBS, and treated with streptavidinbiotin-peroxidase complex for $30 \mathrm{~min}$ at room temperature. The complex was visualized by diaminobenzidine (DAB). Mayer's hematoxylin was used as a counterstain for nuclei. To identify cell types expressing ET-1, double staining using Alcian Blue for the second staining was carried out. After the first immunohistochemical staining with antiET-1 antibody, the sections were immersed in 3\% acetic acid for $1 \mathrm{~min}$ and were then stained with $1 \%$ Alcian Blue in 3\% acetic acid for $30 \mathrm{~min}$. After washing with distilled water for $3 \mathrm{~min}$, counterstaining was carried out with Kernechtrot solution containing 5\% aluminum sulfate and $0 \cdot 1 \%$ Nuclear Fast Red (Wako, Osaka, Japan) for $5 \mathrm{~min}$.
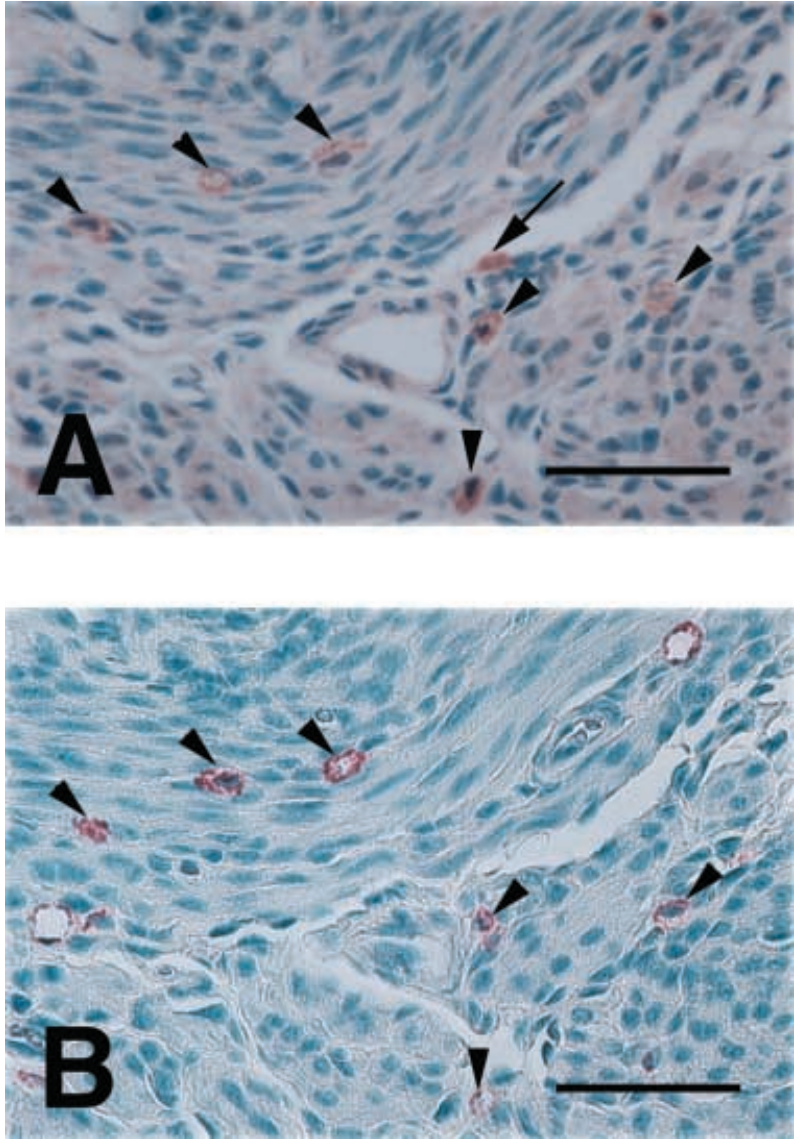

FIGURE 5. Immunostaining for (A) ET-1 and (B) serotonin on serial sections of the uterus at day 0 postpartum. After incubation with anti-ET-1 or anti-serotonin antibody, the specific signals were visualized with DAB (A) or AEC (B). The round- or oval-shaped and ET-1-positive cells in the myometrial layers were also positive for serotonin (arrow heads). A small number of cells positive for ET-1 and negative for serotonin were found (arrow). Counterstaining for nuclei was carried out with Mayer's hematoxylin.

Bars $=50 \mu \mathrm{m}$.

Immunostaining with anti-serotonin rabbit antibody (Chemicon International, Temecula, CA, USA) was performed on serial sections to identify mast cells, which contain serotonin. For visualization of the specific signals, an aminoethylcarbazole (AEC) substrate-chromogen system (DAKO, Carpinteria, CA, USA) was used. Control studies including omission of the primary antibody, incubation with corresponding non-immune serum $\mathrm{IgG}$, and pre-absorption testing using the antibody incubated with an excess of synthetic ET-1 peptide (20 nmol ET-1 to each $1 \mathrm{ml}$ diluted antibody was pre-incubated at $4{ }^{\circ} \mathrm{C}$ for $24 \mathrm{~h}$ ) were performed to assess the specificity of our staining. 


\section{RESULTS}

\section{Gene expression}

We examined the gene expression level of ET-1 in mouse uterus by real-time PCR. Figure 1 shows ET-1 gene expression levels during the estrous cycle. The gene expression rates at proestrus, estrus, and diestrus were low (below one) and almost constant.

We also examined ET-1 mRNA levels in the uterus from pregnant and post-parturient mice (Fig. 2). The gene expression rates during pregnancy were below one and remained almost unchanged. A remarkable increase in expression level was observed after parturition. Immediately after parturition (day 0 postpartum) gene expression reached a maximum (an approximately sixfold increase compared with pregnant levels) and then decreased gradually to basal levels by day 14 postpartum. The levels at day 0 postpartum and at days 1,3 , and 7 postpartum were appreciably higher than during pregnancy and at day 14 postpartum.

\section{Histological study}

To examine the cellular distribution of the ET-1 peptide, we carried out immunohistological studies using an antibody specific to ET-1 peptide. In both cyclic and pregnant mice, weak immunopositivity was observed only in endometrial epithelial cells. Conversely, in the post-paturient uterus discernible immunopositivity was found in endometrial epithelial cells (Fig. 3A) as well as in myometrial cells (Fig. 3B). The strongest staining pattern was observed in myometrial cells in accordance with the maximal level of the gene expression rate, particularly at day 0 postpartum. Additionally, in the early postpartum period we found relatively large, roundor oval-shaped cells, which were intensely positive for ET-1, in the lamina propria, around vessels in the myometrium, and between myometrial cells (Fig. 3C and D). Morphologically these cells were noticeably different from endometrial epithelial cells, stromal cells, and myometrial cells. Almost all the cells were observed in myometrial layers (Fig. 3C). To characterize the cell type, we carried out a double stain with ET-1 antibody and Alcian Blue. Alcian Blue stains acidic mucopolysaccharide, which is abundant in mast cells and epithelial cells of the intestine, salivary gland, uterus and respiratory tract. The large ET-1-positive cells stained positively with Alcian Blue (Fig. 4), suggesting that these are mast cells. We also found a small population of similarly shaped cells negative for
ET-1 but positive for Alcian Blue. These cells could be mast cells which do not contain ET-1 peptide. For further characterization of these cells, immunostainining with ET-1 antibody or serotonin antibody was performed on serial sections, as shown in Fig. 5. The large, round- or oval-shaped cells positive for ET-1 were positively stained by serotonin antibody, indicating that the cells are mast cells. There were also a small number of cells positive for ET-1 and negative for serotonin. In control studies, which included omission of the primary antibody, incubation with corresponding non-immuine serum $\operatorname{IgG}$, and pre-absorption testing, the immunostaining was completely suppressed (Fig. 3E).

\section{DISCUSSION}

In an attempt to understand the importance of ET-1 in mouse uterus, we comprehensively studied the gene expression pattern and cellular distribution of ET-1 during various reproductive periods. In the uterus from cyclic mice we detected a low and constant level of ET-1 expression by real-time PCR and observed faint immunostaining only in endometrial epithelial cells. It has been reported that there is no significant change in the level of immunoreactive ET-1 in sheep uterus, although a small increase was reported to occur at day 16 after estrus, which corresponds almost to the next estrous stage (Riley et al. 1994). Contrary to what has been observed in mouse and sheep, a drastic increase in ET-1 mRNA and peptide levels occurs in the human uterus around menstruation (Ohbuchi et al. 1995, Salamonsen et al. 1999). One possible explanation for the differences in ET-1 expression patterns among these species is that menstruation is observed in the human but not in the mouse or sheep estrous cycle. Human menstruation is accompanied by dramatic endometrial changes including bleeding, deciduation of the zona functionalis, and regeneration. However, in mouse and sheep, the increase in endometrial thickness and the change in histological features are observed to a lesser extent around estrus, but without bleeding or deciduation of the endometrium. It has been suggested that, in humans, ET-1 is involved not only in controlling bleeding by means of its vasoconstricting action and but also in endometrial regeneration following endometrial deciduation by its mitogenic action (Salamonsen et al. 1999). In sheep uterus, expression of ET-1 is affected by ovarian steroids (Riley et al. 1994). We observed a similar phenomenon in mouse uterus in preliminary experiments with exogenous steroid hormones (data 
not shown). However, the amount of progesterone, one of the ovarian steroids, produced by the corpus luteum after ovulation differs among species including humans, and is particularly low in mice. A functional corpus luteum, which secretes progesterone, is formed after ovulation in human and sheep, whereas the mouse corpus luteum does not become functional and secretes almost no progesterone in the absence of the stimulus of coitus. The constancy of the level of ET-1 mRNA in the uterus from the cyclic mouse, compared with human and sheep, may be a consequence of inadequate secretion of progesterone from the corpus luteum after ovulation.

One recent study reports no notable difference in ET-1 mRNA level in the uterus from pregnant rat as determined by Northern blot analysis, although the analysis was limited to only two time points, days 14 and 20 of pregnancy, whereas a large increase was found in the early postpartum period (Kajihara et al. 1996). From these findings, a pivotal role for ET-1 in the cessation of uterine bleeding after parturition through uterine contraction is suggested. In pregnant mice we observed a low and constant level of ET-1 mRNA and found no detectable immunohistological change; we observed similar behavior in the uterus from cyclic mice. However, we did observe a steep rise in the level of ET-1 gene expression and the strongest immunostaining in the myometrium immediately after parturition. The high expression level continues for at least 1 week after parturition and gradually decreases to basal levels by day 14 postpartum. To some degree these findings support the previous findings in rats (Kajihara et al. 1996). However, it is impossible to explain why the expression of ET-1 remains high for more than a week based solely on its role in controlling bleeding immediately after parturition. In fact, conspicuous hemorrhage was not observed after day 3 postpartum in microscopic studies (data not shown). Given the immunopositivity of endometrial epithelium after parturition, the presence of the peptide may be related to endometrial repair as well as to the cessation of bleeding after parturition. As the ET-1 mRNA levels gradually decreased over 14 days postpartum, we also observed a gradual decrease in the thickness of the uterine wall, which was enlarged and thickened for pregnancy, particularly the myometrium (data not shown). It is well known that ET-1 has not only mitogenic activity but also an ability to induce apoptosis via the ETB receptor (Okazawa et al. 1998). In vascular smooth muscle, it has been proposed that ET-1 caused apoptosis via the ETB receptor induced by stretch stimuli (Cattaruzza et al. 2000).
Given the fact that the uterus stretches during pregnancy and at parturition, ET-1 may also be related to apoptosis of myometrial smooth muscle cells via the ETB receptor during uterine recovery.

We noticed some large cells that stained positive for ET-1 which are morphologically different from surrounding stromal and smooth muscle cells in the post-parturient uterus. We identified these cells as mast cells. The role of ET-1 in these mast cells remains unclear. However, considering that the ET-1-positive mast cells were found mainly in intact myometrium but not in or around inflammatory lesions caused by removal of the placenta at parturition, ET-1 may participate via the mast cells in myometrial recovery rather than in inflammation. Moreover, based on the fact that mast cells secrete various proteases, which generate or degrade active ET-1 (Chandrasekharan et al. 1996, Nakano et al. 1997), ET-1 activity on the myometrium may be modulated by the proteases produced by the mast cells. We also found a small number of cells positive for ET-1 and negative for serotonin. Because ET-1 was demonstrated to be present in macrophages (Liu et al. 1998, Li et al. 1999), these cells could be macrophages.

Recently, we carried out a comprehensive analysis of VIC, a member of the mouse endothelin family and the counterpart of human ET-2 (Saida et al. 1989, Bloch et al. 1991), in mouse uterus during the estrous cycle and pregnancy (Uchide et al. 2000b). Uterine VIC mRNA expression levels in the latter half of pregnancy (days $12 \cdot 5$ to $17 \cdot 5$ ) were approximately fivefold higher than in the earlier half (days $7 \cdot 5$ to $12 \cdot 5$ ). In the uterus from cyclic mice, the gene expression level of VIC in proestrus and estrus was about threefold higher than in diestrus. The expression patterns are very different from those of ET-1. This finding suggests that the transcriptional regulation mechanisms for the two genes are distinct in the mouse uterus. Additionally, given that ET-1 and VIC have similar selectivity and affinity for the ETA and ETB receptors (Arai et al. 1990, Sakurai et al. 1990), these two peptides may act cooperatively on the uterus, compensating for each other.

In conclusion, by analyzing ET-1 expression using real-time PCR, we have demonstrated an increased and sustained ET-1 gene expression in the uterus from post-parturient mice. In accordance with increased ET-1 mRNA levels, immunohistochemistry studies showed an intense immunopositivity in myometrial cells and myometrial mast cells after parturition. In mouse uterus ET-1 may play a role in recovery from the uterine changes caused by pregnancy and parturition. 


\section{ACKNOWLEDGEMENTS}

This work was supported by a project grant to Kaname Saida of Research and Development for the Elucidation of Biological Functions from the Ministry of International Trade and Industry of Japan and by a Special Research Grant (No. P0106) to Tsuyoshi Uchide from Kitasato University, School of Veterinary Medicine and Animal Sciences. We gratefully acknowledge the administrative support of Dr Syuichi Oka at AIST and thank Dr Hiroshi Satoh for helpful advice on histopathological analysis. Javier Adur is a recipient of a JICA (Japan International Cooperation Agency) fellowship from the Microscopy Laboratory, Faculty of Bioengineering, National University of Entre Rios, Ruta 11, Km 10 1/2 (3101) Oro Verde, Entre Rios, Argentina.

\section{REFERENCES}

Arai H, Hori S, Aramori I, Ohkubo H \& Nakanishi S 1990 Cloning and expression of a cDNA encoding an endothelin receptor. Nature 348 730-732.

Bloch KD, Hong CC, Eddy RL, Shows TB \& Quertermous T 1991 cDNA cloning and chromosomal assignment of the endothelin 2 gene: vasoactive intestinal contractor peptide is rat endothelin 2. Genomics 10 236-242.

Cameron I, Plumpton C, Champeney R, van Papendorp C, Ashby M \& Davenport A 1993 Identification of endothelin-1, endothelin-2 and endothelin-3 in human endometrium. Fournal of Reproduction and Fertility 98 251-255.

Cattaruzza M, Dimigen C, Ehrenreich H \& Hecker M 2000 Stretch-induced endothelin B receptor-mediated apoptosis in vascular smooth muscle cells. FASEB fournal 14 991-998.

Chandrasekharan UM, Sanker S, Glynias MJ, Karnik SS \& Husain A 1996 Angiotensin II-forming activity in a reconstructed ancestral chymase. Science 271 502-505.

Economos K, MacDonald PC \& Casey ML 1992 Endothelin-1 gene expression and protein biosynthesis in human endometrium: potential modulator of endometrial blood flow. Fournal of Clinical Endocrinology and Metabolism 74 14-19.

Inoue A, Yanagisawa M, Kimura S, Kasuya Y, Miyauchi T, Goto K \& Masaki T 1989 The human endothelin family: three structurally and pharmacologically distinct isopeptides predicted by three separate genes. PNAS 86 2863-2867.

Ishida N, Tsujioka K, Tomoi M, Saida K \& Mitsui Y 1989 Differential activities of two distinct endothelin family peptides on ileum and coronary artery. FEBS Letters 247 337-340.

Kajihara T, Tomioka Y, Hata T, Ghazizadeh M \& Asano G 1996 Synthesis of endothelin-1 in rat uterus during pregnancy. Fournal of Histochemistry and Cytochemistry 44 953-957.

Lahav R, Ziller C, Dupin E \& Le Douarin NM 1996 Endothelin 3 promotes neural crest cell proliferation and mediates a vast increase in melanocyte number in culture. PNAS 93 3892-3897.

Li Z, Miwa Y, Rokutan K \& Nakaya Y 1999 Expression of endothelin-1 in macrophages and mast cells in hyperplastic human tonsils. FEBS Letter 453 381-384.
Liu Y, Yamada H \& Ochi J 1998 Immunohistochemical studies on endothelin in mast cells and macrophages in the rat gastrointestinal tract. Histochemistry and Cell Biology 109 301-307.

Mckay KO, Black JL \& Armour CL 1991 The mechanism of action of endothelin in human lung. European Fournal of Pharmacology 102 422-428.

Maggi M, Vannelli GB, Peri A, Brandi ML, Fantoni G, Giannini S, Torrisi C, Guardabasso V, Barni T, Toscano V, Massi G \& Serio M 1991 Immunolocalization, binding, and biological activity of endothelin in rabbit uterus: effect of ovarian steroids. American Fournal of Physiology 260 E292-E305.

Mazzocchi G, Rossi GP, Rebuffat P, Malendowicz LK, Markowska A \& Nussdorfer GG 1997 Endothelins stimulate deoxyribonucleic acid synthesis and cell proliferation in rat adrenal zona glomerulosa, acting through an endothelin $\mathrm{A}$ receptor coupled with protein kinase $\mathrm{C}$ - and tyrosine kinase-dependent signaling pathways. Endocrinology 138 2333-2337.

Nakano A, Kishi F, Minami k, Wakabayashi H, Nakaya Y \& Kido H 1997 Selective conversion of big endothelins to tracheal smooth muscle-constricting 31-amino acid-length endothelins by chymase from human mast cell. Fournal of Immunology 159 1987-1992.

Ohbuchi H, Nagai K, Yamaguchi M, Ikenoue T, Mori N, Kitamura K, Araki S \& Toshimori K 1995 Endothelin-1 and big-endothelin-1 increase in human endometrium during menstruation. American Fournal of Obstetrics and Gynecology $1731483-1490$

Okazawa M, Shiraki T, Ninomiya H, Kobayashi S \& Masaki T 1998 Endothelin-induced apoptosis of A375 human melanoma cells. Fournal of Biological Chemistry 273 12584-12592.

O'Reilly G, Charnock-Jones D, Davenport A, Cameron I \& Smith S 1992 Presence of messenger ribonucleic acid for endothelin-1, endothelin-2, and endothlin-3 in human endometrium and a change in the ratio of ETA and ETB receptor subtype across the menstrual cycle. Fournal of Clinical Endocrinology and Metabolism 75 1545-1549.

Peri A, Barbara V, Fantoni S, Barni T, Orlando C, Serio M \& Maggi M 1992 Endothelin in rabbit uterus during pregnancy. American Fournal of Physiology 263 E158-E167.

Riley SC, Butt AR, Doughton BW, Li SX, Zheng SH, Findlay JK \& Salamonsen LA 1994 Endothelin in the ovine uterus during the oestrous cycle and early pregnancy. Fournal of Reproduction and Fertility 100 451-459.

Riley SC, Findlay JK \& Salamonsen LA 1995 Endothelin-1 and endothelin receptors are present in the sheep uterus and conceptus at implantation. Fournal of Endocrinology 147 $235-244$.

Rubanyi GM \& Polokoff MA 1994 Endothelins: molecular biology, biochemistry, pharmacology, physiology, and pathophysiology. Pharmacological Reviews 46 325-415.

Saida K, Mitsui Y \& Ishida N 1989 A novel peptide, vasoactive intestinal contractor, of a new (endothelin) peptide family. Molecular cloning, expression, and biological activity. Fournal of Biological Chemistry 264 14613-14616.

Sakurai T, Yanagisawa M, Takuwa Y, Miyazaki H, Kimura S, Goto K \& Masaki T 1990 Cloning of cDNA encoding a non-isopeptide-selective subtype of the endothelin receptor. Nature 348 732-735.

Salamonsen LA, Marsh MM \& Findlay JK 1999 Endometrial endothelin: regulator of uterine bleeding and endometrial repair. Clinical and Experimental Pharmacology and Physiology 26 154-157. 
Uchide T, Hiromi M, Mitsui Y \& Saida K 1999 Gene expression of vasoactive intestinal contractor/endothelin-2 in ovary, uterus, and embryo: comprehensive gene expression profiles of the endothelin ligand-receptor system revealed by semi-quantitative reverse transcription-polymerase chain reaction analysis in adult mouse tissues and during late embryonic development. Fournal of Molecular Endocrinology 22 161-171.

Uchide T, Adur J \& Saida K 2000a Rapid quantification of murine endothelin-1 and vasoactive intestinal contractor gene expression levels by a real-time PCR system. Fournal of Biotechnology 84 187-192.
Uchide T, Masuda H, Lee YS, Makiyama Y, Mitsui Y \& Saida K $2000 b$ Fluctuating gene expression and localized cellular distribution of vasoactive intestinal contractor (VIC) in mouse uterus. Fournal of Histochemistry and Cytochemistry 48 699-707.

Yanagisawa M, Kurihara H, Kimura S, Tomobe Y, Kobayashi M, Mitsui Y, Yazaki Y, Goto K \& Masaki T 1988 A novel potent vasoconstrictor peptide produced by vascular endothelial cells. Nature $332411-415$.

RECEIVED 30 March 2001

ACCEPTED 1 June 2001 